Гарнага О. М. [1; ORCID ID: 0000-0002-5236-7299], к.е.н., доцент

${ }^{1}$ Національний університет водного господарства та природокористування, м. Рівне

\title{
ТЕОРЕТИКО-МЕТОДИЧНІ АСПЕКТИ РОЗВИТКУ ОРЕНДНО-ЗЕМЕЛЬНИХ ВІДНОСИН
}

У статті розглянуто теоретико-методичні аспекти розвитку орендноземельних відносин. Наголошено, що одним із основних завдань підвищення ефективності діяльності агропромислового комплексу країни є екологізація використання земельно-природного потенціалу та розвиток ефективних орендно-земельних відносин у сільському господарстві. При цьому важливо зазначити, що розвиток орендноземельних відносин залежить від політичних, економічних, фізичних та організаційних факторів.

Ключові слова: орендно-земельні відносини; земельно-природний потенціал; оренда землі; сільськогосподарське виробництво; договір оренди.

Вступ. Одним із основних завдань підвищення ефективності діяльності агропромислового комплексу країни $\epsilon$ екологізація використання земельно-природного потенціалу та розвиток ефективних орендно-земельних відносин у сільському господарстві. Залучення усіх форм власності на землі сільськогосподарського призначення, трансформація орендних земельних відносин об'єктивно спричинили формування новітніх нормативів та правил використання, відтворення та охорони земельно-ресурсного комплексу країни. Крім того, розроблені механізми управління земельними та, зокрема, земельно-орендними відносинами, які використовуються у сільському господарстві, адміністративні та фіскальні важелі абсолютно не несуть у собі економічного стимулювання власників та користувачів сільськогосподарських угідь до раціонального використання та відтворення земельних ресурсів, а відповідно і не здатні ефективно впливати на діяльність суб'єктів оренди землі щодо дотримання вимог державної екологічної політики та розвитку сталого природокористування.

Аналіз останніх досліджень і публікацій. Дослідженню проблемних аспектів орендно-земельних відносин у сільському 
господарстві значну увагу приділено в наукових працях Данкевича В. Є., Іванюка І. В., Ільків Н. В., Кірейцевої О. В., Саблука П.Т., Третяка А. М., Хвесика М.А. та інших вчених. Звісно, багато питань залишаються ще не до кінця дослідженими i потребують подальшої поглибленої розробки теоретичних i методичних аспектів щодо вивчення розвитку орендно-земельних відносин.

Постановка завдання. Мета статті полягає в дослідженні теоретико-методичних аспектів розвитку орендно-земельних відносин.

Викладення основного матеріалу. В сучасних умовах сільськогосподарського виробництва основоположними у системі суспільних відносин є земельні відносини, оскільки земля виступає водночас і засобом, і предметом праці, тобто $€$ основним виробничим ресурсом [1, С. 18]. У свою чергу, розвиток ефективного землекористування в системі сільського господарства $\epsilon$ фундаментом відтворювальних процесів в аграрній сфері суспільного виробництва та соціальній інфраструктурі сільських територій, виступає як обов'язковий принцип господарювання сільськогосподарських товаровиробників [2, С. 7].

В економічному сенсі земельні відносини трактуються як вольові суспільні відносини, що мають об'єктивний характер і можуть розглядатися як економічні відносини [3, С. 9]. Тобто, коли на сьогодні земля відноситься до сфери сільськогосподарського виробництва як матеріальний фактор, вона стає об'єктом платного володіння і користування, зумовлюючи економічно-правовий характер земельних відносин [4, С. 18], який базується на сплаті земельного податку за земельні ділянки та земельні частки (паї), що знаходяться у приватній власності, і виплаті орендної або якоїсь іншої узгодженої плати за користування земельними ділянками сільськогосподарського призначення інших власників.

Володіння землею - це юридично гарантована непорушність права власності на землю та невід'ємність цього права без особистого волевиявлення землевласника чи землекористувача або за інших умов, визначених законодавством. Законодавча спроможність володіти землею надає можливість носію такого права враховувати земельні ресурси на балансі, включати земельні видатки до собівартості товарної продукції сільського господарства, відображати виробничі витрати на утримання та експлуатацію земельного фонду у бухгалтерській звітності. 
Користування землею - це юридично гарантоване право господарювання на землі, використовуючи її природні властивості для виробництва товарної продукції та отримання земельного рентного доходу або одержання операційного доходу під час надання приватних земельних ділянок у платне строкове користування іншим землекористувачам.

Розпорядження землею - це юридично надана можливість визначати правову долю земельної ділянки 3 урахуванням їі цільового призначення. Правомочність розпорядження землею проявляється у тому, що носій такого права може на свій власний розсуд продати земельну ділянку, надати їі в оренду, подарувати, обміняти тощо.

Таким чином, розглядаючи структуру законодавчо зафіксованих земельних відносин сільськогосподарського товаровиробника, ми виокремлюємо юридично дозволені фінансовоматеріальні взаємовідносини між безпосереднім виробником сільськогосподарської продукції та:

- органами державної влади, міськими, селищними та сільськими радами як власниками сільськогосподарських земель;

- громадянами (фізичними особами) - власниками земельних часток (паїв) та земельних ділянок сільськогосподарського призначення;

- юридичними особами - власниками сільськогосподарських земельних угідь, які вони надають у користування на правах оренди сільськогосподарському виробнику.

Отже, суб'єктами земельних відносин у законодавчо визначеному полі можуть бути громадяни, юридичні особи, органи місцевого самоврядування та органи державної влади. Сільськогосподарськими товаровиробниками, в межах юридично дозволених в Україні організаційно-правових форм утворення цих структур, визнають сільськогосподарські підприємства державної і приватної власності громадян та юридичних осіб (підприємства, господарські товариства і виробничі кооперативи), фермерські господарства та господарства населення (в т.ч. господарства фізичних осіб-підприємців, які здійснюють свою господарську діяльність у галузі сільськогосподарського виробництва).

Пристосування земельних відносин до ринкових умов господарювання поряд 3 довготривалим проведенням земельної реформи спричинили появу невирішених проблем у системі їх управління. Внаслідок проведення широкомасштабної земельної 
реформи та запровадження ринкових принципів господарювання відбулися істотні зміни в сфері сільського господарства, зокрема у орендно-земельних відносинах. У сільському господарстві цей вид відносин став основним елементом у формуванні нових умов господарювання. Оренда землі набула іншого характеру та змісту.

Право оренди земель $€$ особливим видом земельних правовідносин. Суб'єктами цих правовідносин виступають власники земельних ділянок (орендодавці) і орендарі. На відміну від інших титульних правових можливостей на земельну ділянку, визначених законом, суб'єкти орендно-земельних відносин мають можливість встановлювати і змінювати свої права та обов'язки. Це не $\epsilon$ притаманним для інших титульних землевласників та землекористувачів.

Власник земельної ділянки має можливість отримати дохід від свого права на неї трьома способами:

а) продати її за найвищою ціною;

б) самостійно використовувати ї̈ як засіб власного виробництва, як об'єкт господарювання;

в) передати всю земельну ділянку або визначену їі частину у строкове платне користування іншим особам, іншими словами - в оренду.

Стосовно першого випадку, то тут власник отримавши певну вигоду від договору купівлі-продажу ділянки повністю припиняє своє право власності на неї.

У другому випадку власник, використовуючи свою земельну ділянку як господарюючий суб'єкт, сам отримує дохід від цієї діяльності.

В третьому випадку орендар отримує земельну ділянку в строкове платне розпоряджання і користування та зобов'язується періодично передавати власнику частину отриманого ним доходу у вигляді орендної плати. При цьому інтереси сторін повинні бути зазначені в письмовому договорі, який вони укладають. Власник земельної ділянки без жодних витрат отримує дохід, а орендар отримує право вільно і самостійно господарювати на землі.

Проте, варто зазначити, що орендар все таки обмежений певними умовами, до яких відносять:

а) використовувати орендовану земельну ділянку потрібно за цільовим призначенням;

б) своєчасно сплачувати орендну плату; 
в) охороняти землю як природний ресурс і об'єкт господарювання.

Орендар розпоряджається і користується земельною ділянкою як умовою виробництва і засобом (об'єктом) господарювання. Оскільки поняття оренди виникає, як правило, з метою ведення підприємницької діяльності, то інтерес орендаря виявляється в тому, що він стає власником виготовленої продукції, робіт і послуг на орендованій земельній ділянці та привласнює собі дохід від їх реалізації.

Змістом орендно-земельних відносин є суб'єктивні права та юридичні обов'язки орендодавця та орендаря, які визначаються Законом України «Про оренду землі».

До основних обов'язків орендаря відносять:

- використання земельної ділянки за цільовим призначенням згідно з договором оренди;

- додержання екологічної безпеки землекористування та збереження родючості ґрунтів, дотримання державних стандартів, норм і правил, у тому числі місцевих правил забудови населених пунктів;

- додержання режиму водоохоронних 3он, прибережних захисних смуг, зон санітарної охорони, санітарно-захисних зон, зон особливого режиму використання земель та територій, які особливо охороняються;

- своєчасної сплати орендної плати.

Заключаючи договір орендодавець повинен:

- передати земельну ділянку в користування у такому стані, який відповідає умовам договору оренди;

- при здійсненні передачі земельної ділянки в оренду забезпечити, згідно з законом, реалізацію прав третіх осіб щодо орендованої земельної ділянки;

- не вчиняти будь яких дій, які б перешкоджали орендареві користуватися орендованою земельною ділянкою;

- відшкодувати орендарю капітальні витрати, пов'язані 3 поліпшенням стану об'єкта оренди, що здійснювалося орендарем за згодою орендодавця;

- завчасно попередити орендаря про особливі властивості та недоліки об'єкта оренди, які в процесі використання можуть спричинити екологічно небезпечні наслідки для навколишнього середовища.

Орендар має право: 
- самостійно здійснювати господарську діяльність на земельній ділянці з дотриманням умов договору оренди землі;

- за згодою орендодавця зводити в установленому законодавством порядку жилі, виробничі, культурно-побутові та інші будівлі і споруди;

- отримувати продукцію і доходи;

- здійснювати в установленому законодавством порядку за згодою орендодавця будівництво водогосподарських споруд та меліоративних систем.

Згідно ст. 763 ЦК України, за загальним правилом договір оренди укладається на визначений термін. Якщо ж строк оренди в договорі не прописано, то договір оренди вважається укладеним на невизначений термін. Оренда - це право, що діє протягом часу, обумовленого в договорі, після закінчення якого орендоване майно земля підлягає поверненню орендодавцю, тобто власнику земельної ділянки.

Законом також можуть визначатися максимальні (граничні) строки договору для окремих видів оренди. Так, Земельним кодексом закріплена короткострокова оренда - не більше 5 років, довгострокова оренда - не більше 50 років. Законом України «Про внесення змін у Закон України «Про оренду землі» у редакції від 2 жовтня 2003 р. запроваджено, що строк оренди землі визначається за згодою сторін, але він не може перевищувати 50 років (стаття 19).

Для прикладу наведемо умови оренди сільськогосподарських земель в деяких країнах світу.

Таблиця

Умови оренди земель в різних країнах світу [5]

\begin{tabular}{|l|l|}
\hline \multicolumn{1}{|c|}{ Країна } & \multicolumn{1}{|c|}{ Термін дії договору оренди } \\
\hline Бельгія & мінімум - 12 років, максимум - 99 років \\
\hline Греція, Ірландія & мінімум - 3-4 роки \\
\hline Данія & максимум - 30 років \\
\hline Ізраїль & максимум - 99 років \\
\hline Іспанія & мінімум - 6 років, максимум - 15 років \\
\hline Італія & $\begin{array}{l}\text { мінімальний термін - 15 років для низинних } \\
\text { земель, а для гірських - 6 років }\end{array}$ \\
\hline Люксембург & $\begin{array}{l}\text { мінімум - 6 років для земельної ділянки, 8 років } \\
\text { - для всього господарства }\end{array}$ \\
\hline Нідерланди & $\begin{array}{l}\text { мінімум - 6 років для земельної ділянки без } \\
\text { споруд, 12 років - для всього господарства }\end{array}$ \\
\hline
\end{tabular}


продовження таблиці

\begin{tabular}{|l|l|}
\hline Німеччина & $\begin{array}{l}\text { суд по с.-г. спорах може продовжити термін } \\
\text { максимум на } 12 \text { років для окремих ділянок } \\
\text { землі, і на } 18 \text { років щодо господарства в цілому }\end{array}$ \\
\hline Норвегія & $\begin{array}{l}\text { при укладанні орендних договорів строком } \\
\text { більш, ніж на } 10 \text { років потрібен дозвіл влади }\end{array}$ \\
\hline Україна & максимум 50 років \\
\hline Франція & мінімум - 12 років, максимум - 25 років \\
\hline Швеція & мінімум - 10 років \\
\hline
\end{tabular}

Слід зазначити, що також на розвиток орендно-земельних відносин впливають такі фактори [6]:

- політичні;

- економічні;

- організаційні;

- фізичні.

Політичні характеризують відносини власності на них. Ці фактори проявляються через дії органів державної влади, яка визначає форми власності на землю, механізм набуття права власності відповідними суб'єктами господарювання тощо.

Економічні чинники стосуються, в першу чергу, організації раціонального використання землі. Система орендних відносин передбачає набуття права користування землею та перехід цього права від одного користувача до іншого. Саме у створенні умов для ефективного використання земельних ресурсів й полягає значення економічної функції орендно-земельних відносин.

Щодо організаційних факторів орендно-земельних відносин, то частіше за все мається на увазі:

- принцип визначення орендної плати (нормативний, контрактивний, ринковий);

- строк оренди;

- укладення договору оренди на конкурсній основі;

- обмеження та обтяження стосовно використання земельної ділянки;

- форма орендної плати;

- укладення договору з об'єднанням власників земельних паїв;

- інші.

Фізичні фактори, як правило, пов'язані 3 природними характеристиками земельної ділянки. До них належать:

- розташування, конфігурація, розмір земельного масиву; 
- рельєф;

- характеристика ґрунтів; вид угідь тощо.

Висновки. Отже, в статті досліджено теоретико-методичні аспекти розвитку орендно-земельних відносин. Наголошено, що оренда сільськогосподарських земель $\epsilon$ ефективним різновидом ринкових відносин і може бути альтернативою купівлі-продажу. Визначено, що функція держави у орендно-земельних відносинах, а також у захисті інтересів землевласників, повинна бути визначальною. Ефективна реалізація таких функцій держави має забезпечуватись послідовним моніторингом орендно-земельних відносин державними інституціями. Орендні земельні відносини забезпечать отримання бажаного ефекту лише за умов державної, правової, фінансової та організаційної підтримки, належної законодавчої бази, а також соціальної справедливості.

1. Дехтяренко Ю. Ф. Методичні основи грошової оцінки земель в Україні : навч. посіб. К. : Профі, 2007. 624 с. 2. Земельний кодекс України: діюче законодавство 3 коментарями. Х. : 000 «Одисей», 2002. 600 с. 3. Семчик В.І. Проблеми права власності та господарювання у сільському господарстві: монографія. К. : Ін-т держави і права ім. В.М. Корецького НАН України, 2008. 216 с. 4. Корнєєв Ю. В. Земельне право : навч. посіб. К. : Центр учбової літератури, 2009. 240 с. 5. Макаренко А. П. Теорія і практика державного регулювання в аграрній сфері: монографія. К. : ННЦ «Інститут аграрної економіки» УААН, 2009. 636 с. 6. Богач Л. В. Організаційно-економічна оцінка функціонування аграрних формувань на основі оренди сільськогосподарських земель. Науковий вісник Національного університету біоресурсів і природокористування України. 2014. Вип. 200. С. 41-47.

\section{REFERENCES:}

1. Dekhtiarenko Yu. F. Metodychni osnovy hroshovoi otsinky zemel v Ukraini : navch. posib. K. : Profi, 2007. 624 s. 2. Zemelnyi kodeks Ukrainy: diiuche zakonodavstvo z komentariamy. Kh. : 000 «Odysei», 2002. 600 s. 3. Semchyk V. I. Problemy prava vlasnosti ta hospodariuvannia u silskomu hospodarstvi : monohrafiia. K. : In-t derzhavy i prava im. V.M. Koretskoho NAN Ukrainy, 2008. 216 s. 4. Kornieiev Yu. V. Zemelne pravo : navch. posib. K. : Tsentr uchbovoi literatury, 2009. 240 s. 5. Makarenko A. P. Teoriia i praktyka derzhavnoho rehuliuvannia $v$ ahrarnii sferi : monohrafiia. K. : NNTs «Instytut ahrarnoi ekonomiky» UAAN, 2009. 636 s. 6. Bohach L. V. Orhanizatsiinoekonomichna otsinka funktsionuvannia ahrarnykh formuvan na osnovi orendy silskohospodarskykh zemel. Naukovyi visnyk Natsionalnoho universytetu bioresursiv $i$ pryrodokorystuvannia Ukrainy. 2014. Vyp. 200. S. 41-47. 
Harnaha O. M. [1; ORCID ID: 0000-0002-5236-7299], Candidate of Economics (Ph.D.), Associate Professor

${ }^{1}$ National University of Water and Environmental Engineering, Rivne

\section{THEORETICAL AND METHODOLOGICAL ASPECTS OF THE DEVELOPMENT OF LEASE-LAND RELATIONS}

The article considers the theoretical and methodological aspects of the development of lease and land relations. It is emphasized that one of the main tasks of increasing the efficiency of the agro-industrial complex of the country is the greening of land and natural resources and the development of effective lease and land relations in agriculture.

In modern conditions of agricultural production, land relations are fundamental in the system of social relations, because the land is both a means and an object of labor, it is the main production resource.

Subjects of lease and land relations in the legally defined field can be citizens, legal entities, local governments, and public authorities.

As a general rule, the lease agreement is concluded for a specified period. If the lease term is not specified in the contract, the lease agreement is considered concluded for an indefinite period. Lease is a right that is valid for the period stipulated in the contract, after which the leased property the land is subject to return to the lessor, the owner of the land.

It is important to note that the development of lease and land relations depends on political, economic, physical, and organizational factors.

Political factors of lease-land relations characterize the relationship of ownership of them. These factors are manifested through the actions of public authorities, which determine the forms of land ownership, the mechanism of acquisition of ownership by the relevant entities, and so on.

Economic factors relate primarily to the organization of rational land use.

It is emphasized that the lease of agricultural land is an effective type of market relations and can be an alternative to buying and selling. It is determined that the function of the state in lease and land relations, as well as in protecting the interests of landowners, should be decisive. The effective implementation of such functions of the state should be ensured by consistent monitoring of lease and land relations by state institutions. Lease land relations will ensure the desired effect only in terms of state, legal, financial, and organizational support, proper legal framework, as well as social justice.

Keywords: lease-land relations; land-natural potential; land lease; agricultural production; lease agreement. 


\section{ТЕОРЕТИКО-МЕТОДИЧЕСКИЕ АСПЕКТЫ РАЗВИТИЯ АРЕНДНО- ЗЕМЕЛЬНЫХ ОТНОШЕНИЙ}

В статье рассмотрены теоретико-методические аспекты развития арендно-земельных отношений. Отмечено, что одной из основных задач повышения эффективности деятельности агропромышленного комплекса страны является экологизация использования земельноприродного потенциала и развитие эффективных арендно-земельных отношений в сельском хозяйстве. При этом важно отметить, что развитие арендно-земельных отношений зависит от политических, экономических, физических и организационных факторов.

Ключевые слова: арендно-земельные отношения; земельноприродный потенциал; аренда земли; сельскохозяйственное производство; договор аренды.

Отримано: 15 вересня 2021 p. Прорецензовано: 18 вересня 2021 р. Прийнято до друку: 24 вересня 2021 р. 